\title{
Comparative Analysis of Tryptophan Oxygenase Activity and Glucocorticoid Receptor under the Influence of Insulin
}

\author{
E. R. ISENOVIĆ ${ }^{1}$, Z. ZAKULA ${ }^{2}$, G. KORICANAC ${ }^{2}$, N. RIBARAC-STEPIĆ ${ }^{2}$ \\ Vinca Institute of Nuclear Sciences, ${ }^{1}$ Laboratory for Molecular Genetics and Radiobiology and \\ ${ }^{2}$ Laboratory for Molecular Biology and Endocrinology, 11000 Belgrade, Serbia
}

Received October 5, 2006

Accepted December 14, 2006

On-line January 2, 2007

\section{Summary}

This investigation addresses the interaction of insulin (INS) and glucocorticoid (GC) signaling in the hepatic regulation of tryptophan oxygenase (TO) enzyme activity in the rat. Male Wistar rats (200-250 g b.w) received an injection of the different doses of INS $(10,25,50,70$ and $100 \mu \mathrm{g} / 200 \mathrm{~g}$ b.w., i.p.) and were used for experiments $3 \mathrm{~h}$ and $18 \mathrm{~h}$ after INS administration. This study shows that maximum of TO activity was found at dose of $50 \mu \mathrm{g}$ of INS with peak increases observed at $3 \mathrm{~h}$ and $18 \mathrm{~h}$ after injection of INS, while INS had no effect on TO activity in adrenalectomized rats. The analysis of INS effects on glucocorticoid receptor-complex (GC/GR complex) stability shows that complexes from INS-treated rats are less stable than those from control animals. In addition, INS-stimulated stability of glucocorticoid receptor (GR) protein was significantly increased from the controls. Furthermore, the results show that GC/GR complexes from INS-treated rats could be activated and accumulated at higher rate in cell nuclei of control animals. These data support the involvement of INS in modulation of GC signaling pathway which mediates, in part, the activity of TO.

\section{Key words \\ Glucocorticoid - Glucocorticoid receptor - Stability of glucocorticoid-receptor complex • Insulin • Tryptophan oxygenase}

\section{Corresponding author}

Esma R. Isenovic, Vinca Institute of Nuclear Sciences, Laboratory for Molecular Genetics and Radiobiology 11000 Belgrade, Serbia, E-mail: isenovic@yahoo.com

\section{Introduction}

Various hormones, such as insulin (INS) and glucocorticoids (GC), elicit their effects on the activity of the same enzymes in spite of the differences in their chemical nature and the specificity in the molecular mechanism of their action on the common target cells (Hirota et al. 1985, Schubart 1986). The consequences of transmission and transduction of hormone signals to their target cells comprise the regulation of gene expression involved in concomitant modification of cell function. All of these effects INS and GC are realized through hormone binding to specific receptors (White and Kahn 1994, Schaaf and Cidlowski 2002, Schoneveld et al. 2004).

The first step in INS action is the binding of INS to the specific plasma membrane receptors (IR). At the molecular level, INS binding to its transmembrane IR stimulates the intrinsic tyrosine kinase activity of the receptor, which then phosphorylates target protein such as family of IR substrate proteins (De Meyts 2004). This triggers the activities of downstream effectors molecules comprised by two major kinase cascades, the phosphatidylinositol 3-kinase and mitogen-activated protein (MAP) kinase pathways, which mediate the metabolic and growth-promotion function of INS respectively (Whitehead et al. 2000).

It is generally accepted that molecular mechanism of GC action includes binding of the $\mathrm{GC}$ to the specific cytoplasmic receptor, i.e. glucocorticoidreceptor (GR), activation of the GR and transport of the glucocorticoid receptor-complex (GC/GR complex) into the nucleus (Cidlowski and Munck 1979, Schoneveld et 
al. 2004). In this way, GR becomes ligand activated transcription factor, known to regulate gene expression and cell functions (Schoneveld et al. 2004).

In mammals, most of the total tryptophan is degraded through the kynurenine pathway in the liver. The first enzyme of tryptophan oxidation is tryptophan oxygenase (TO; EC.1.13.11.11) (Comings et al. 1995). Expression of TO is an interesting model system for studying the control mechanism of gene expression, since the enzyme is expressed in a tissue-specific fashion, and its activity is a subject to hormonal control (Danesch et al. 1987). In addition to rapid effects of GC and INS to modify hepatic glucose output by regulating gluconeogenesis at the level of enzymes directly involved in this process, e.g. phosphoenolpyruvate carboxykinase (PEPCK), these agents also affect gluconeogenesis through altered synthesis of certain enzymes of amino acid metabolism (Exton 1987). TO and tyrosine aminotransferase are also regulated by GC and INS in part at the level of specific messenger RNA synthesis (Danesch et al. 1987, Schubart 1986).

The specific effects of steroids on target gene and also their influence on the cell-specific transcriptional modulation could be insured through synergistic action of these hormones and their receptors with other transcriptional factors. It has been reported that INS is an essential component for the transcriptional regulation of liver-specific genes in combination with GC (Pan and Koontz 1995). However, the molecular mechanism(s) of multihormonal regulation of cell processes as well as the levels at which the integration of hormonal effects occurs in target cells are not completely understood. In order to gain more information on the participation of INS in transduction of GC signals in the regulation of cell functions, the possible interactions between INS and GC in the regulation of TO activity via rat liver GC signaling pathway have been studied. This investigation has been based on hypothesis that INS enhances the ability of GC to increase TO activity by interfering with signaling through GR in the rat liver.

\section{Methods}

\section{Chemicals}

$1,2,4(\mathrm{n})\left[{ }^{3} \mathrm{H}\right]$-triamcinolone acetonide $\left(\left[{ }^{3} \mathrm{H}\right] \mathrm{TA}\right)$ specific activity $32 \mathrm{Ci} / \mathrm{mmol}$ was obtained from Amersham (Amersham International, UK). Porcine insulin was obtained from ICN-Galenika, Belgrade, Serbia \& Montenegro. All other chemicals were obtained from Sigma (Sigma, St. Louis, USA).

\section{Animals and treatment}

Male Wistar rats (2-2.5 months old; 200-250 g b.w.) were kept at $22{ }^{\circ} \mathrm{C}$, with a $12 / 12 \mathrm{~h}$ light-dark schedule (rat chow and water ad libitum) and for some experiments were bilaterally adrenalectomized under Nesdonal anesthesia 5 days prior to the experiment. Animals were divided into two experimental groups (3 rats per group): control (CONT) and insulin (INS)treated. After an overnight fast, animals were injected intraperitoneally with different doses of INS (10, 25, 50, 70 and $100 \mu \mathrm{g} / 200 \mathrm{~g}$ b.w.) and sacrificed at different time (3, 6, 12, 18 and $24 \mathrm{~h}$ ) after INS administration. The CONT animals were used after an overnight fast, received $0.14 \mathrm{M} \mathrm{NaCl}$, kept at room temperature and sacrificed along with their INS-treated counterparts. Experimental protocols were approved by local Ethical Committee and they were in compliance with „Good Laboratory Animal Practice“.

\section{Tryptophan oxygenase assay}

Tryptophan oxygenase activity was assayed in crude liver homogenates essentially described previously (Hirota et al. 1981, Knox and Auerbach 1955). One unit of TO activity was defined as the amount of kynurenine/ $\mathrm{h} / \mathrm{g}$ of dry weight of liver homogenates at $25^{\circ} \mathrm{C}$.

\section{Preparation of hepatic cytosol and nuclei}

The animals were killed by cervical dislocation and livers were perfused in situ with ice cold saline through portal vein. The livers were quickly removed, weighed, minced and homogenized with Potter-Elvejhem homogenizer in 2 volumes $(\mathrm{w} / \mathrm{v})$ of a $50 \mathrm{mM}$ Tris buffer, $\mathrm{pH} 7.55$, containing $0.25 \mathrm{M}$ sucrose, $25 \mathrm{mM} \mathrm{KCl}, 10 \mathrm{mM}$ $\mathrm{MgCl}_{2}$ and $0.1 \mathrm{mM}$ PMSF. The homogenate was centrifuged at $800 \mathrm{xg}$ for $10 \mathrm{~min}$, at $4{ }^{\circ} \mathrm{C}$. To obtain the cytosolic fraction the supernatant was centrifuged at $105000 \mathrm{x} \mathrm{g}$ for $90 \mathrm{~min}$. The upper lipid layer was aspirated and clear cytosol was used for GR analysis (Beato and Feigelson 1972, Schoneweld et al. 2004). For isolation of nuclei, the crude nuclear pellet, obtained after the first centrifugation, was resuspended in a cold buffer, $\mathrm{pH} 7.2$, containing $2.2 \mathrm{M}$ sucrose, $5 \mathrm{mM}$ Tris- $\mathrm{HCl}, 5 \mathrm{mM}$ $\mathrm{CaCl}_{2}$, layered over the same cold solution and centrifuged at $24000 \mathrm{rpm}$ for $60 \mathrm{~min}$ at $4{ }^{\circ} \mathrm{C}$ in a Beckman SW 27 rotor. The resultant pellet of nuclei was washed three times with a buffer containing $5 \mathrm{mM}$ Tris$\mathrm{HCl}$ and $1 \mathrm{mM} \mathrm{MgCl} 2, \mathrm{pH} 7.9$ and kept in the same 
buffer supplemented with $25 \%$ glycerol at $4{ }^{\circ} \mathrm{C}$ until use (Chauveau et al. 1956).

\section{Stability of GR and GC/GR complex}

The unliganded GR in the freshly prepared rat liver cytosol was first subjected to the activation at $23{ }^{\circ} \mathrm{C}$ for different time period $(0,15,30,60,120$, and 180 $\mathrm{min})$. Cytosol aliquots were then incubated with $20 \mathrm{nM}$ $\left[{ }^{3} \mathrm{H}\right] \mathrm{TA}$ for $2 \mathrm{~h}$ at $4{ }^{\circ} \mathrm{C}$ to form GC/GR complexes. For determining the rate of dissociation of GC/GR complexes at $23{ }^{\circ} \mathrm{C}$, a series of tubes containing aliquots of cytosol were first complexed with $20 \mathrm{nM}\left[{ }^{3} \mathrm{H}\right] \mathrm{TA}$ at $4{ }^{\circ} \mathrm{C}$ for $2 \mathrm{~h}$. After charcoal treatment a 1000 -fold excess of radio inert TA was added to each tube and samples were incubated at $23{ }^{\circ} \mathrm{C}$ for different time intervals $(0,15,30,60,120$, and $180 \mathrm{~min})$. At the end of each time period, samples were treated with dextran-coated charcoal in order to determine the amount of bound radioactivity (Isenovic et al. 2006a).

Translocation of $\left[^{3} \mathrm{H}\right]$ TA-receptor complexes into the isolated nuclei

Complexes formed during incubation of the cytosolic fraction with $20 \mathrm{nM}$ of $\left[{ }^{3} \mathrm{H}\right] \mathrm{TA}$ at $4{ }^{\circ} \mathrm{C}$ for $18 \mathrm{~h}$ were activated by exposure to $25^{\circ} \mathrm{C}$ for $30 \mathrm{~min}$ (Parchman and Litwack 1977), and then samples were treated with dextran-coated charcoal $(3.75 \%$ Norit A and $0.375 \%$ dextran $\mathrm{T}-500$ in buffer for homogenization) to separate bound and free hormones. Samples were then centrifuged at $2000 \times \mathrm{g}$ for $10 \mathrm{~min}$ at $4{ }^{\circ} \mathrm{C}$ and the clear supernatants were kept at $4{ }^{\circ} \mathrm{C}$ until use. For the translocation assay purified nuclei were incubated $30 \mathrm{~min}$ at $4{ }^{\circ} \mathrm{C}$ with the same volumes of activated or nonactivated hormone-receptor complexes. Following incubation the samples were washed three times with buffer containing $5 \mathrm{mM}$ Tris- $\mathrm{HCl}$ and $1 \mathrm{mM} \mathrm{MgCl}_{2}, \mathrm{pH}$ 7.9 , and centrifuged each time for $10 \mathrm{~min}$ at $800 \mathrm{x}$ g. The final pellets were then resuspended in buffer containing $0.01 \mathrm{M}$ Tris- $\mathrm{HCl}, 0.3 \mathrm{M} \mathrm{NaCl}, 1 \mathrm{mM} \beta$-mercaptoethanol, $1 \mathrm{mM}$ EDTA, $0.5 \mathrm{mM} \mathrm{MgCl}_{2}, \mathrm{pH} 8.0$, and mixed at $10 \mathrm{~min}$ intervals for $30 \mathrm{~min}$ at $4{ }^{\circ} \mathrm{C}$. The suspensions were centrifuged $20 \mathrm{~min}$ at $12000 \mathrm{xg}$ and the resulting supernatant was used for determination of radioactivity and protein concentration. The extracted radioactivity was measured and expressed as disintegrations per minute per milligram of protein. In some experiments, the pellet, referred as the nuclear fraction insoluble in $0.3 \mathrm{M}$ $\mathrm{NaCl}$, was extracted overnight with absolute ethanol and centrifuged at $12000 \times \mathrm{g}$ for $20 \mathrm{~min}$. The extracted radioactivity was measured and expressed as disintegrations per minute per milligram of pelleted DNA (Hirota et al. 1985, Schubart 1986).

\section{Determination of protein and DNA}

Protein content was determined by the method of Lowry (1951) using bovine serum albumin as a standard. DNA content was measured by the method of Burton (1956).

\section{Measurement of radioactivity}

For radioactivity measurements the samples were directly introduced into $3 \mathrm{ml}$ of Optiphase Hisafe scintillation cocktail and counted in 1219 Rackbeta liquid scintillation counter (LKB) at an efficiency of about $30 \%$ and with automatic cpm/dpm calculation.

\section{Statistical analysis}

Values are expressed as mean \pm SE with $n$ values representing the number of experiments. Each experiment was performed five times using 3 rats per group. Statistical significance was evaluated with Student's T-test or ANOVA (Moore et al. 1951). A value of $\mathrm{p}<0.05$ was considered significant (compared to control values if it is not otherwise specified).

\section{Results}

Figure 1 presents group of data comparing the effect of different doses of INS (10, 25, 50, 70 and 100 $\mu \mathrm{g} / 200 \mathrm{~g}$ b.wt. i.p.) injected for $3 \mathrm{~h}$ into rats, on TO activity. It can be seen that a dose of $50 \mu \mathrm{g}$ of INS induced maximum TO activity. This increase in TO activity was $97 \%$ because mean TO activity increased from control $1.22 \pm 0.13 \mu \mathrm{mol}$ to $2.40 \pm 0.23 \mu \mathrm{mol}$ following the $50 \mu \mathrm{g}$ of INS injection.

Figure 2 demonstrates the effect of the $50 \mu \mathrm{g}$ of INS on enzyme activity as a function of time after INS injection. These increases in TO activity were $96 \%$ (at $3 \mathrm{~h}$ ) and $60 \%$ (at $18 \mathrm{~h}$ ) of control.

It should, however, be noted that INS injected into bilaterally adrenalectomized rats, decreases TO activity compare to sham-operated rats (Isenovic et al. 2006a).

Figure 3 illustrates the effects of INS effects on GC/GR complex (panel A) and GR protein stability (panel B). GC/GR complexes formed from INS-treated rats are less stable than those from control animals, whereas injection of INS significantly stimulated stability 

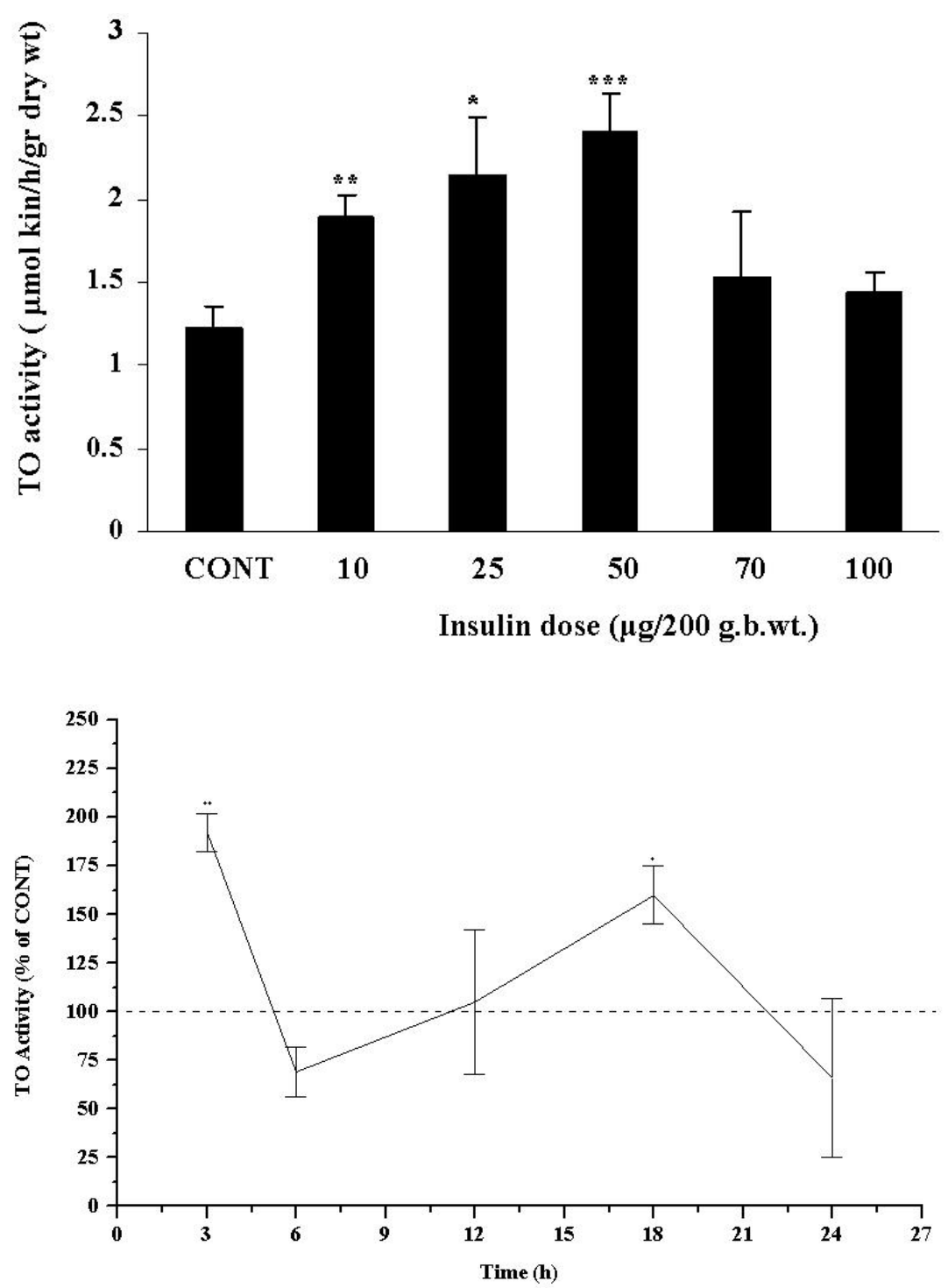

Fig. 1. Dose-dependent effects of INS on TO activity determined $3 \mathrm{~h}$ after administration of different doses of INS $(10,25,50,70$ and $100 \mu \mathrm{g} / 200 \mathrm{~g}$ b.w.) as described in section Material and Methods. The enzyme activity is presented as amount of kynurenine/ $\mathrm{h} / \mathrm{g}$ of dry weight of rat liver homogenate. Each bar represents the mean \pm S.E.M. of 5 experiments. $* * * \mathrm{p}<0.001$, $* * \mathrm{p}<0.01, * \mathrm{p}<0.05$ INS vs. CONT. CONT indicates control; INS indicates insulin treatment for $3 \mathrm{~h}$.

Fig. 2. Time-dependent effects of INS on TO activity determined after INS administration $(50 \mu \mathrm{g} / 200 \mathrm{~g}$ b.w. $)$ at different time intervals $(3,6,12,18$ and $24 \mathrm{~h}$ ) as described in section Material and Methods. The enzyme activity is presented as \% increase vs. CONT. Each bar represents the mean \pm S.E.M. of 5 experiments. ${ }^{* * p}<0.01$; ${ }^{*} p<0.05$. CONT indicates control; INS indicates insulin $(50 \mu \mathrm{g} / 200 \mathrm{~g}$ b.w.) of GR protein.

Figure 4 exemplifies the effects of INS on nuclear translocation of in vitro formed ${ }^{3} \mathrm{H}$-triamcinolone acetonide $\left({ }^{3}\right.$ HTA-R) complexes. It can be seen that different level of translocated ${ }^{3}$ HTA-R complexes has been observed in isolated nuclei after administration of INS, implying that liver cytosol ${ }^{3}$ HTA-R complexes from INS-treated rats could be activated by heat and translocated into isolated nuclei from the same livers at lower rate than those from the controls.

\section{Discussion}

In this study we have examined: 1) the effects of INS on TO activity, 2) the involvement of the adrenal gland in the effects of INS on TO activity and 3) the effects of INS on GR and GC/GR complex stability and nuclear translocation. The present study demonstrated that the maximum TO activity was found at a dose of $50 \mu \mathrm{g}$ of INS (Fig. 1). These findings are of interest because it is well accepted that INS induced the activity of TO in cultured rat hepatocytes (Schubart 1986). In addition, we demonstrated that the peak of increase in TO activity was observed at $3 \mathrm{~h}$ and at $18 \mathrm{~h}$ of exposure to INS (Fig. 2). These findings highlight key differences in mechanisms underlying TO induction following stimulation by INS. One mechanism (peak at $3 \mathrm{~h}$ ) could be explained by tryptophan accumulation in hepatocytes as a result of INS effects on the increased amino acid transport from extra hepatic tissues (Goldstein et al. 1962, Kim and Miller 1969), whereas the other (peak at $18 \mathrm{~h}$ ) could reflect INS effects on the enzyme synthesis. In addition, Niimi et al. (1983) and Schubart (1986) demonstrated that regulation of TO activity by various hormones is due to a change in its translatable mRNA. However, the change of the mRNA can be explained by 


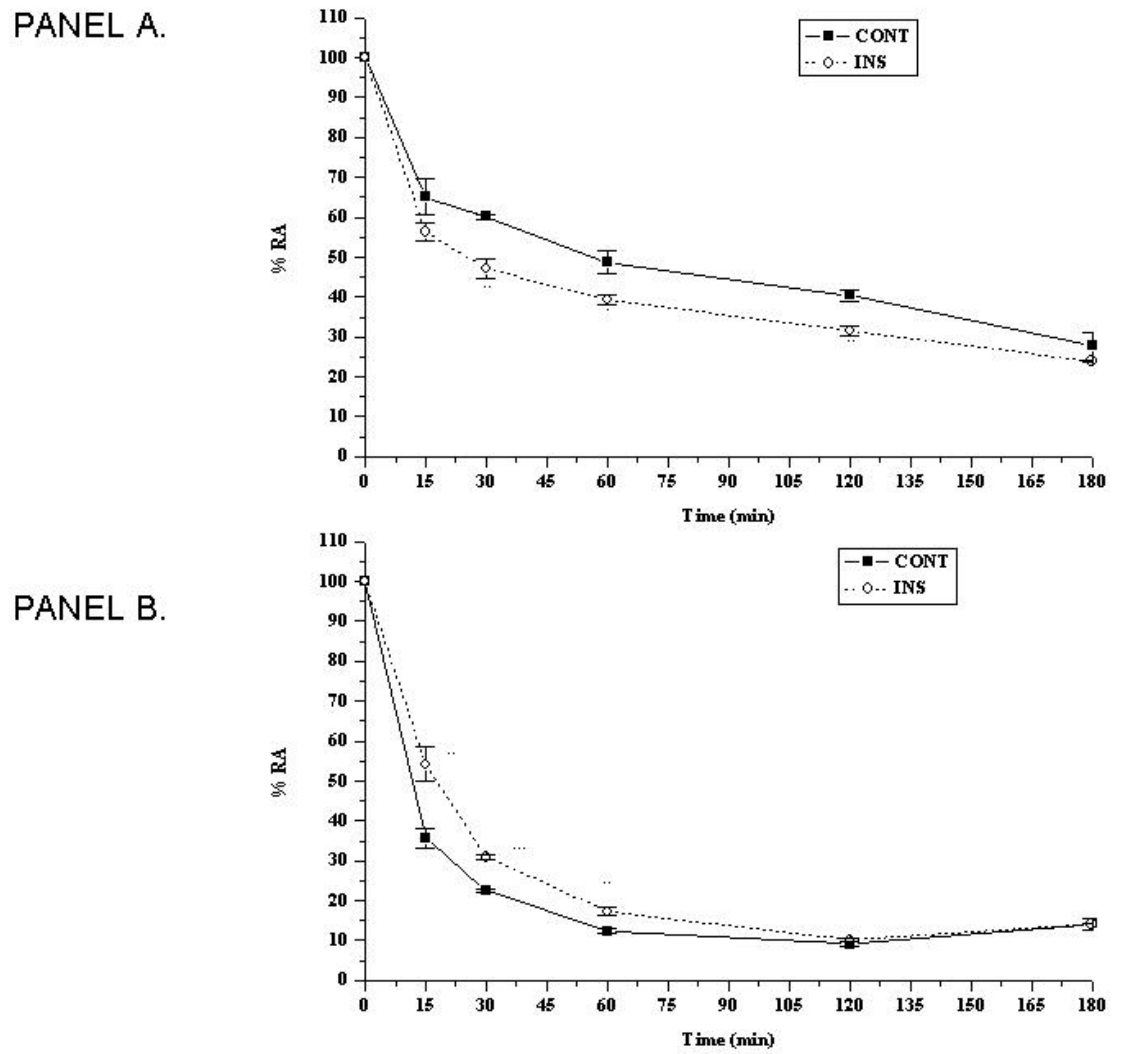

Fig. 3. Effects of INS on GC/GR complex (A) and GR stability (B) A. Aliquots of rat liver cytosol from CONT and INS-treated animals, were incubated with $20 \mathrm{nM}$ $\left[{ }^{3} \mathrm{H}\right] \mathrm{TA}$ for $2 \mathrm{~h}$ at $4{ }^{\circ} \mathrm{C}$. After charcoal treatment a 1000-fold excess of unlabeled TA was added to each tube and samples were incubated at $23^{\circ} \mathrm{C}$ for different time periods shown. After the incubation, the mixtures were treated with charcoal in order to determine the amount of bound radioactivity. The results present $\%$ of bound radioactive $\left[{ }^{3} \mathrm{H}\right] \mathrm{TA}$. Each bar represents the mean \pm S.E.M. of 5 experiments. $* * p<0.01, * p<0.05$.

B. Series of tubes was containing aliquots of rat liver cytosol from control and INStreated animals were first incubated in the absence of steroid at $23^{\circ} \mathrm{C}$ for time period shown. At the end of each time, cytosols were incubated with $20 \mathrm{nM}\left[{ }^{3} \mathrm{H}\right] \mathrm{TA}$ for $2 \mathrm{~h}$ at $4{ }^{\circ} \mathrm{C}$ for determination of bound radioactivity, as described in Materials and Methods. The results represent the mean \pm S.E.M. of 5 experiments are expressed as $\%$ of bound radioactive $\left[{ }^{3} \mathrm{H}\right] \mathrm{TA}$. $* * * p<0.001, * * p<0.01$. CONT indicates control, INS indicates insulin $(50 \mu \mathrm{g} / 200 \mathrm{~g}$ b.w.) for $3 \mathrm{~h}$; $\left[{ }^{3} \mathrm{H}\right]$ TA indicates triamcinolone acetonide. change in either its transcription or stability. Using this cDNA, Nakamura et al. (1987) measured the effects of hormones on the amount of TO mRNA by dot-blot hybridization and the relative rate of transcription of the TO gene by nuclear run-off with its cDNA as a probe. Their results indicated that changes in TO mRNA level were due to changes in regulation of its transcription. Since administration of INS to intact rats leads to elevation of TO activity (Isenovic et al. 2006a,b), it is possible to assume that INS provokes the interaction of unliganded GR with GC response elements (GREs) and in this way INS contributes to the enhancement of TO transcription (Pan and Koontz 1995). However, most of the INS-stimulated TO activity in rat liver was inhibitable by adrenalectomy (Isenovic et al. 2006a), suggesting that INS stimulation of the TO was largely dependent of GC presence. Taken together, these findings support our idea that 1) INS and GC may act in parallel signaling pathways, both of which are necessary for the regulation of TO, and 2) there is a cross-talk between INS and GC where INS is activated first, which is further resulting in the activation and/or induction of synthesis of GR. If induction or activation of GR is needed for the action of INS, this would explain why INS fails to induce TO after adrenalectomy (Isenovic et al. 2006a).

If the main effect of INS is mediated by GR, it is probably directed to the induction of TO gene transcription through GC response elements in this gene (Danesch et al. 1987). There is also a possibility that INS-stimulated amino acid uptake in liver cells induces TO activity by substrate induction (Fehlmann et al. 1979). Finally, it is well known that direct INS effect on TO mRNA exists (Niimi et al. 1983). The consequence of the increased tryptophan catabolism, i.e. TO activity, could be a stimulation of gluconeogenesis and glucose production in the liver (Exton 1987).

It must also be noted that our previous study provided evidence for the stimulatory effect of INS on GR protein expression (Isenovic et al. 1993, 2006a) as well as on functional properties of GR (Isenovic et al. 2006a), and indicated a role of INS in GR regulation. The present study indicates that INS injection significantly increased GC/GR complex dissociation (Fig. 3A) and GR protein stability (Fig. 3B). Furthermore, INS-stimulated GR stability is in conjunction with decreased GC/GR complex translocation (Fig. 4). These changes of GC/GR complexes stability under INS action could result from increased nuclear translocation of the receptor or from its posttranslational modifications such as phosphorylation/ dephosphorylation which is proposed to maintain the receptor in a conformation state necessary for ligand binding activity (Weigel 1996). Phosphorylation of GR 


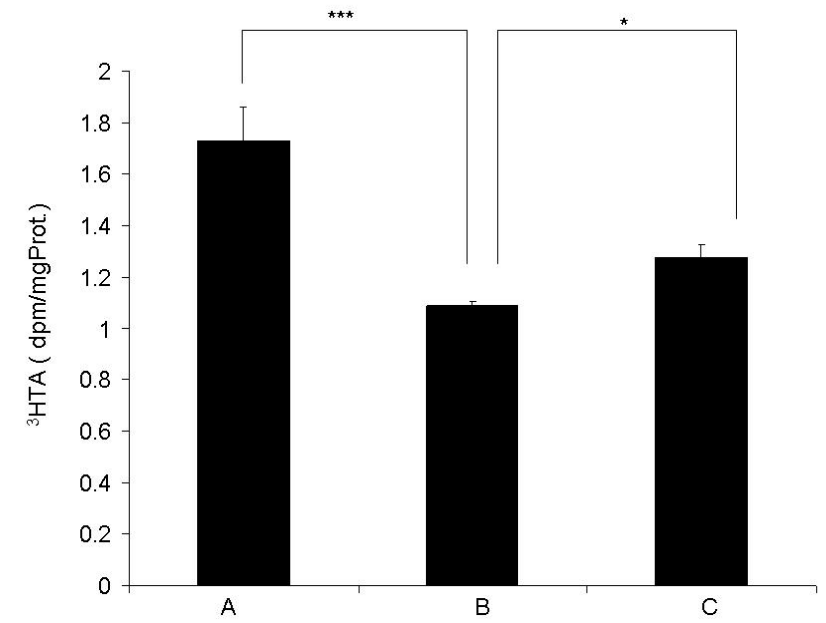

Fig. 4. The effect of INS on nuclear translocation of $\left.{ }^{3} \mathrm{H}\right] \mathrm{TA}-\mathrm{R}$ complexes. Isolated liver nuclei from control (A) and INS (B) treated rats were incubated with cytosol ${ }^{3} \mathrm{HTA}-\mathrm{R}$ complexes prepared from liver of the respective group of animals and (C) control nuclei were incubated with ${ }^{3} \mathrm{HTA}-\mathrm{R}$ complexes obtained from liver cytosol following INS treatment as described in section Material and Methods. The extracted radioactivity was measured and expressed as disintegrations per minute per milligram of protein (dpm/mg Prot.). Each bar represents the mean \pm S.E.M. of 5 experiments. $* * * p<0.001$ and $* p<0.05$. CONT indicates control. INS indicates insulin $\left(50 \mu \mathrm{g} / 200 \mathrm{~g}\right.$ b.w. ) for $3 \mathrm{~h}$; $\left[{ }^{3} \mathrm{H}\right]$ TA indicates triamcinolone acetonide.

upon the activation of receptor complex, which could be modulated by protein hormones via kinase activity of their membrane receptors, might provide a molecular basis for the interaction and integration of multiple effects and response of common target cells to INS and GC hormone action (Kuiper and Brinckmann 1994, O'Malley 1995). In addition, the presented results show that administration of INS induced changes in distribution of CG/GR complexes between cytosol and nuclei of the liver cells (Fig. 4).

These data (Fig. 4) together with our earlier results (Isenovic et al. 1993, 2006a,b) suggest that INS treatment causes the modification(s) of GR at the level of interaction with nuclear components. On the basis of the presented results it could be concluded that the activation and translocation of $\mathrm{GC} / \mathrm{GR}$ complexes into the nuclei might be one of the possible sites where the interaction of the GC and INS is achieved in regulation of cell processes.

In summary, consistent evidence is emerging that TO activity and functional properties of GR are altered by INS injection. Based on these findings, we suggest that INS treatment might activate the GC signaling pathway, participating in the regulation of $\mathrm{TO}$ activity in the rat liver.

\section{Conflict of Interest}

There is no conflict of interest.

\section{Acknowledgements}

This study was supported by Serbian Ministry of Science and Environment Protection (Grant N 143030 B to E.R.I).

\section{References}

BEATO M, FEIGELSON P: Glucocorticoid-binding proteins of rat liver cytosol. I. Separation and identification of the binding proteins. J Biol Chem 247: 7890-7896, 1972.

BURTON K: A study of the conditions and mechanism of the diphenylamine reaction for the colorimetric estimation of deoxyribonucleic acid. Biochem J 62: 315-323, 1956.

CHAUVEAU J, MOULE Y, ROUILLER C: Isolation of pure and unaltered liver nuclei morphology and biochemical composition. Exp Cell Res 11: 317-321, 1956.

CIDLOWSKI JA, MUNCK A: Heterogeneity of nuclear glucocorticoid receptor interactions. Adv Exp Med Biol 117: 71-93, 1979.

COMINGS DE, MUHLEMAN D, DIETZ G, SHERMAN M, FOREST GL: Sequence of human tryptophan 2, 3dioxygenase (TDO2): presence of a glucocorticoid response-like element composed of a GTT repeat and an intronic CCCCT repeat. Genomics 29: 390-396, 1995.

DANESCH U, GLOSS B, SCHMID W, SCHUTZ G, SCHULE R, RENKAWITZ R: Glucocorticoid induction of the rat tryptophan oxygenase gene is mediated by two widely separated glucocorticoid-responsive elements. Embo $J$ 6: 625-630, 1987.

DE MEYTS P: Insulin and its receptor: structure, function and evolution. Bioessays 26: 1351-1362, 2004.

EXTON JH: Mechanisms of hormonal regulation of hepatic glucose metabolism. Diabetes Metab Rev 3: 163-183, 1987. 
FEHLMANN M, LE CAM A, FREYCHET P: Insulin and glucagon stimulation of amino acid transport in isolated rat hepatocytes. Synthesis of a high affinity component of transport. J Biol Chem 254: 10431-10437, 1979.

GOLDSTEIN L, STELLA EJ, KNOX WE: The effect of hydrocortisone on tyrosine-alpha-ketoglutarate transaminase and tryptophan pyrrolase activities in the isolated, perfused rat liver. J Biol Chem 237: 1723-1726, 1962.

HIROTA T, YOSHIKAZU S, TANAKA T: Dexamethasone control of the development of tryptophan oxygenase in young rats. Life Sci 28: 2161-2166, 1981.

HIROTA T, HIROTA K, SANNO Y, TANAKA T: A new glucocorticoid receptor species: relation to induction of tryptophan dioxygenase by glucocorticoids. Endocrinology 117: 1788-1795, 1985.

ISENOVIC E, ZAKULA Z, RADOJCIC M, RIBARAC-STEPIC N: Effects of insulin on the level of glucocorticoid receptors. Med Pregl 46 (Suppl 1): 94-95, 1993.

ISENOVIC ER, ZAKULA Z, KORICANAC G, RIBARAC-STEPIC N: Insulin modulates rat liver glucocorticoid receptor. Acta Biol Hung 57: 37-48, 2006 a.

ISENOVIC ER, RADOJCIC M, ZAKULA Z, KORICANAC G, RIBARAC-STEPIC N: Effect of acute adrenalectomy on rat liver glucocorticoid receptor. Arch Biol Sci 58: 153-159, $2006 \mathrm{~b}$.

KIM JH, MILLER LL: The functional significance of changes in activity of the enzymes, tryptophan pyrrolase and tyrosine transaminase, after induction in intact rats and in the isolated, perfused rat liver. $J$ Biol Chem 244: 1410-1416, 1969.

KNOX WE, AUERBACH VH: The hormonal control of tryptophan peroxidase in the rat. J Biol Chem 214: 307-313, 1955.

KUIPER GG, BRINKMANN AO: Steroid hormone receptor phosphorylation: is there a physiological role? Mol Cell Endocrinol 100: 103-107, 1994.

LOWRY OH, ROSEBROUGH NJ, FARR AL, RANDALL RJ: Protein measurement with the Folin phenol reagent. J Biol Chem 193: 265-275, 1951.

MOORE F, CRAMER F, KNOWIES R: Statistics for Medical Students. Blakiston Company, Philadelphia, 1951.

NAKAMURA T, NIIMI S, NAWA K, NODA C, ICHIHARA A, TAKAGI Y, ANAI M, SAKAKI Y: Multihormonal regulation of transcription of the tryptophan 2,3-dioxygenase gene in primary cultures of adult rat hepatocytes with special reference to the presence of a transcriptional protein mediating the action of glucocorticoids. J Biol Chem 262: 727-733, 1987.

NIIMI S, NAKAMURA T, NAWA K, ICHIHARA A: Hormonal regulation of translatable mRNA of tryptophan 2,3dioxygenase in primary cultures of adult rat hepatocytes. J Biochem (Tokyo) 94: 1697-1706, 1983.

O'MALLEY BW: Thirty years of steroid hormone action: personal recollections of an investigator. Steroids 60: 490498, 1995.

PAN L, KOONTZ J: Insulin enhances glucocorticoid receptor-mediated induction of gene expression independent of a specific insulin response element. Arch Biochem Biophys 316: 886-892, 1995.

PARCHMAN LG, LITWACK G: Resolution of activated and unactivated forms of the glucocorticoid receptor from rat liver. Arch Biochem Biophys 183: 374-382, 1977.

SCHAAF MJ, CIDLOWSKI JA: Molecular mechanisms of glucocorticoid action and resistance. J Steroid Biochem Mol Biol 83: 37-48, 2002.

SCHONEVELD OJ, GAEMERS IC, LAMERS WH: Mechanisms of glucocorticoid signalling. Biochim Biophys Acta 1680: 114-128, 2004.

SCHUBART UK: Regulation of gene expression in rat hepatocytes and hepatoma cells by insulin: quantitation of messenger ribonucleic acid's coding for tyrosine aminotransferase, tryptophan oxygenase, and phosphoenolpyruvate carboxykinase. Endocrinology 119: 1741-1749, 1986.

WEIGEL NL: Steroid hormone receptors and their regulation by phosphorylation. Biochem J 319: 657-667, 1996.

WHITE MF, KAHN CR: The insulin signaling system. J Biol Chem 269: 1-5, 1994.

WHITEHEAD JP, CLARK SF, URSO B, JAMES DE: Signaling through the insulin receptor. Curr Opin Cell Biol 12: $222-228,2000$. 